\title{
Stable isotope analysis of diet confirms niche separation of two sympatric species of Namib Desert lizard
}

\author{
Ian W. Murray, ${ }^{1}$ Hilary M. Lease, ${ }^{1,2}$ Robyn S. Hetem, ${ }^{1}$ Duncan Mitchell, ${ }^{1}$ Andrea Fuller ${ }^{1}$ \\ and Stephan Woodborne $e^{3,4}$ \\ ${ }^{1}$ Brain Function Research Group, School of Physiology, Faculty of Health Sciences, University of the \\ Witwatersrand, Johannesburg, South Africa, \\ ${ }^{2}$ Biology Department, Whitman College, Walla Walla, Washington, USA, \\ $3_{\text {iThemba Laboratories, Gauteng, South Africa and }}$ \\ ${ }^{4}$ Stable Isotope Laboratory, Mammal Research Institute, Department of Zoology and Entomology, University of \\ Pretoria, Pretoria, South Africa
}

\begin{abstract}
We used stable isotopes of carbon and nitrogen to study the trophic niche of two species of insectivorous lizards, the Husab sand lizard Pedioplanis husabensis and Bradfield's Namib day gecko living sympatrically in the Namib Desert. We measured the $\delta^{13} \mathrm{C}$ and $\delta^{15} \mathrm{~N}$ ratios in lizard blood tissues with different turnover times (whole blood, red blood cells and plasma) to investigate lizard diet in different seasons. We also measured the $\delta^{13} \mathrm{C}$ and $\delta^{15} \mathrm{~N}$ ratios in available arthropod prey and plant tissues on the site, to identify the avenues of nutrient movement between lizards and their prey. Through the use of stable isotope mixing models, we found that the two lizard species relied on a largely non-overlapping but seasonally variable array of arthropods: $P$. husabensis primarily fed on termites, beetles and wasps, while $R$. bradfieldi fed mainly on ants, wasps and hemipterans. Nutrients originating from $\mathrm{C}_{3}$ plants were proportionally higher for $R$. bradfieldi than for $P$. husabensis during autumn and late autumn/early winter, although not summer. Contrary to the few available data estimating the trophic transfer of nutrients in ectotherms in mixed $\mathrm{C}_{3}$ and $\mathrm{C}_{4}$ /crassulacean acid metabolism (CAM) plant landscapes, we found that our lizard species primarily acquired nutrients that originated from $\mathrm{C}_{4} / \mathrm{CAM}$ plants. This work adds an important dimension to the general lack of studies using stable isotope analyses to estimate lizard niche partitioning and resource use.
\end{abstract}

Key words: Namib Desert, niche partitioning, Pedioplanis, Rhoptropus, stable isotopes

Correspondence: Ian W. Murray, Brain Function Research

Group, School of Physiology, Faculty of Health Sciences, University of the Witwatersrand, Johannesburg, South Africa. Email: Ian.Murray@wits.ac.za

\section{Introduction}

For all species there exists a particular set of biotic and abiotic conditions that bound their existence, which may be thought of as the species' niche (Hutchinson 1957). Species niches can be characterized by habitat 
requirements, geographical distribution, thermal niches or other dimensions, which may not be independent of each other. Resource use is one niche dimension that is widely studied because the resources that organisms use play an important role in determining species diversity, and may allow different species within a similar feeding guild to coexist in the same habitat (Simberloff \& Dayan 1991). Within the same feeding guild, a species may be a resource specialist or a resource generalist (Futuyma \& Moreno 1988). Habitats usually will be able to support a greater number of specialist species that consume non-overlapping resources than generalist species that overlap in their resource consumption (Roughgarden 1974). This is due to competitive exclusion, the theory that two similar species are unable to coexist with one another unless there is some level of divergence in how they use resources (Hardin 1960; Pianka 1974). Indeed, a basic premise of community ecology is that the coexistence of otherwise similar species within a feeding guild may be accomplished by the use of distinct resources (MacArthur 1958; Bowers \& Brown 1982).

Research on lizard community structure and function has been important for characterizing the concept of the species niche, as well as understanding how different species coexist (e.g., Schoener 1977; Pianka 1986). Arid ecosystems in particular may be ideal places to examine species niche partitioning because in such environments lizard diversity is often high, it can be relatively easy to secure large samples of individual lizards (Pianka 1986), and limited resources have the potential to intensify competition (MacArthur \& Levins 1967). For example, despite the low availability of plant resources, the Namib Desert is home to a diverse lizard fauna with high levels of endemism (Robinson \& Cunningham 1978; Murray \& Schramm 1987; Herrmann \& Branch 2013), and, as with other hot deserts, high lizard biomass may represent an important component of the food web in this ecosystem (Pianka 1986). However, few studies to date have examined resource partitioning and trophic dynamics within the Namib lizard fauna (Robinson \& Cunningham 1978; Murray \& Schramm 1987; Murray et al. 2016).

The use of stable isotopes, particularly carbon $\left(\delta^{13} \mathrm{C}\right)$ and nitrogen $\left(\delta^{15} \mathrm{~N}\right)$ stable isotopes, is an effective and minimally invasive way to quantify the spatial and temporal patterns of consumer resource partitioning (Gannes et al. 1997; Boecklen et al. 2011). Because tissue $\delta^{15} \mathrm{~N}$ increases by approximately $3.0 \%$, on average, across each trophic level within a food web, $\delta^{15} \mathrm{~N}$ may be used as an indication of an organism's trophic level (DeNiro \& Epstein 1981; Peterson \& Fry 1987). Conversely, tissue $\delta^{13} \mathrm{C}$ changes very little (approximately $0-1.0 \%$ ), on average, across trophic levels within a food web; consequently, $\delta^{13} \mathrm{C}$ may be used to trace carbon sources (DeNiro \& Epstein 1978; Peterson \& Fry 1987). During photosynthesis plants discriminate against carbon dioxide molecules containing the ${ }^{13} \mathrm{C}$ isotope. However, due to differences in the enzymes responsible for carboxylation, plants which use the $\mathrm{C}_{3}$ photosynthetic pathway (e.g. trees and most forbs) have significantly lower ${ }^{13} \mathrm{C}$ values compared to plants that use either the $\mathrm{C}_{4}$ (e.g. many grasses) or crassulacean acid metabolism (CAM; many succulents) photosynthetic pathway. These differences lead to $\mathrm{C}_{3}$ plants having a lower $\delta^{13} \mathrm{C}$ ratio compared to $\mathrm{C}_{4} / \mathrm{CAM}$ plants (Ehleringer et al. 1986, 1997). $\mathrm{C}_{3}$ and $\mathrm{C}_{4} / \mathrm{CAM}$ plants also have important structural differences (e.g. $\mathrm{C}_{4}$ plants are characterized by Kranz anatomy, which includes the presence of thick-walled bundle sheath cells), which influence their nutritional profitability to consumers, and may have distinct growth responses to seasonal patterns of precipitation and climate (Ode et al. 1980; Schulze et al. 1996; Barbehenn et al. 2004a,b; Muldavin et al. 2008). Consequently, ecosystem primary productivity can be divided into distinct resource compartments based on plant photosynthetic pathways.

Importantly, the physiological differences between $\mathrm{C}_{3}$ and $\mathrm{C}_{4} / \mathrm{CAM}$ plants mean that they are likely to be affected differently under current projections of climate change and enhanced atmospheric $\mathrm{CO}_{2}$ levels (IPCC 2014). For example, higher $\mathrm{CO}_{2}$ levels may improve $\mathrm{C}_{3}$ plant nutrient and water use efficiency, and favor plants with high demands for woody structural tissue, such as trees, compared to herbaceous plants, such as grasses (most of which are $\mathrm{C}_{4}$ in arid regions; Drake et al. 1997; Bond et al. 2003). However, warmer and drier climatic conditions would tend to favor $\mathrm{C}_{4} / \mathrm{CAM}$ plants (Bond et al. 2003). From a consumer's perspective these differences matter because many animals selectively forage on either $\mathrm{C}_{3}$ or $\mathrm{C}_{4} / \mathrm{CAM}$ plants, and the nutritional quality of these plant groups is not the same (Ehleringer et al. 2002; Barbehenn et al. 2004a,b). Furthermore, enhanced $\mathrm{CO}_{2}$ levels may translate into negative consumer effects due to lower plant tissue nitrogen content and higher carbon to nitrogen ratios (Ehleringer et al. 2002).

Here we investigate and compare the resource partitioning of 2 sympatric and similarly-sized species 
of insectivorous Namib lizards. The Husab sand lizard, Pedioplanis husabensis Berger-Dell'Mour \& Mayer, 1989 , is a $2.5-3.0$-g lacertid lizard endemic to rocky substrates in the west-central Namib Desert between the ephemeral Swakop and Khan Rivers (Berger-Dell'Mour \& Mayer 1989). Bradfield's Namib day gecko, Rhoptropus bradfieldi Hewitt, 1935, is a 3.0-4.0-g rockdwelling diurnal gecko endemic to the Namib Desert (Branch 1998). We examine the trophic niches for each of these lizard species by analyzing the carbon and nitrogen stable isotope ratios in plant tissues, available arthropod prey and lizard tissues. Because P. husabensis and $R$. bradfieldi differ in their foraging strategy and habitat use (Murray et al. 2014, 2015), we predict that there will be significant differences between their trophic niches, evidenced by different tissue isotope values.

\section{Materials and Methods}

\section{Study site}

Our study site is along the dry Swakop River, Namibia, at Hildenhof, approximately $40 \mathrm{~km}$ east of Swakopmund $\left(22^{\circ} 42.049^{\prime} \mathrm{S}, 14^{\circ} 54.890^{\prime} \mathrm{E} ; 210 \mathrm{~m}\right.$; see Murray et al. [2014, 2015] for further details) in the Namib Desert. The dry riverbed vegetation is characterized by a riparian woodland consisting of scattered trees and shrubs including Vachellia erioloba (camelthorn), Tamarix usneoides (tamarisk), Faidherbia albida (ana tree), Euclea pseudebenus (wild ebony) and Salvadora persica (mustard bush), growing in and along the edges of the sandy riverbed (Cowlishaw \& Davies 1997). Adjacent to the riverbed are bare rocky slopes sparsely-covered with small shrubs such as Arthraerua leubnitziae (pencil bush) and Sesuvium sesuvoides (desert pink). A narrow zone of more densely-spaced shrubs such as Zygophyllum stapffii (dollar bush), Lycium sp. and Salsola sp. (salt bush) is situated on the silty substrates where the rocky slopes meet the river channel. Perennial grasses make up a small proportion of plant cover and generally are restricted to the edges of the river channel (I. Murray, personal observation). The study site is in a hyper-arid system with mean annual precipitation of approximately $25 \mathrm{~mm}$, and $25-$ 50 fog days per year may be expected based on data from other similar sites (Olivier 1995; Haensler et al. 2011; Eckardt et al. 2013). After sporadic precipitation events, such as one during April 2013, annual grasses such as Stipagrostis sp. were also evident.

\section{Lizard tissue collection}

We captured lizards during austral summer (December 2012-January 2013) and austral autumn (May 2013) using noose poles. We took blood samples (approximately $50 \mu \mathrm{L}$ ) from the infraorbital sinus with heparinized capillary tubes before releasing the lizards unharmed (Murray et al. 2014). All procedures were approved by the University of the Witwatersrand's Animal Ethics Screening Committee (clearance certificate number 2012/50/03) and were in accordance with the Namibian Ministry of Environment and Tourism Research/Collecting Permit 1744/2012.

We collected whole blood from adult lizards of both species between December 2012 and January 2013 (austral summer), and in May 2013 (austral autumn/ early winter). Blood was sampled from 21 male and 5 female $P$. husabensis and 13 male and 8 female $R$. bradfieldi during austral summer, and 17 male and 26 female $P$. husabensis and 7 male and 11 female $R$. bradfieldi in austral autumn.

We centrifuged the blood samples collected in autumn to separate out the plasma and red blood cells (RBC). Plasma was not available for the blood that we collected during summer because we used the plasma water for the determination of field metabolic rates (Murray et al. 2014, 2015). We air-dried RBC and loaded approximately $0.4 \mathrm{mg}$ of $\mathrm{RBC}$ and dried whole blood into $4 \times 6$-mm tin cups (Costech Analytical Technologies, California, USA; \#041070). In addition, we pipetted approximately $15 \mu \mathrm{L}$ of plasma into 4 $\times 6-\mathrm{mm}$ tin cups immediately after centrifuging and air-dried the samples before folding the tin cups for analysis. We did not extract lipids from the blood samples because blood contains too little lipid to confound analyses (Bearhop et al. 2000). Due to small blood volumes, several of the $R$. bradfieldi samples did not yield large enough nitrogen peaks to be analyzed by isotope ratio mass spectrometry, resulting in fewer nitrogen isotope ratios being reported than carbon ratios. For several additional samples we did not have sufficient RBC sample masses to run either carbon or nitrogen. We lost several plasma samples in the mass spectrometer.

In small insectivorous lizards, plasma has a carbon retention time (the average amount of time a carbon atom is retained in tissue and a means to estimate tissuespecific turnover times; Martínez del Rio \& AndersonSprecher 2008) of 25 days while RBC have a carbon retention time of 61 days (Warne et al. 2010b). Because 
plasma and RBC have different biological turnover rates, their isotope ratios reflect dietary history over both short (plasma) and long (RBC) periods (Boecklen et al. 2011). Consequently, plasma from blood collected in May reflected diet in late autumn/early winter, and $\mathrm{RBC}$ from blood collected in May reflected diet during autumn. Although plasma was unavailable for blood collected in summer, the use of whole blood is well established in the published literature (e.g. Boecklen et al. 2011) for estimating diet. The carbon retention time for whole blood is unknown for lizards, but because it is likely to have a retention time between that of plasma (25 days) and RBC (61 days), with RBC largely driving whole blood carbon retention times (Flaherty et al. 2010; Warne et al. 2010b), we can confidently make the assumption that isotope ratios in whole blood collected in summer reflect early summer diet.

\section{Characterization of plant and arthropod}

\section{resources}

We collected tissue from 30 plant species on the site during May 2013, which represented a majority of the species growing during our lizard sampling activity. We sampled multiple leaves and stems from 3 to 5 randomly selected plants of each species and stored them in paper envelopes. The plant tissues were dried in an oven at $55^{\circ} \mathrm{C}$ and samples were homogenized with a clean mortar and pestle to create a homogenate for each species. We analyzed the carbon and nitrogen stable isotope ratios for each species using aliquots (approximately $1 \mathrm{mg}$ ) of the dried homogenate.

We sampled arthropods from areas where lizards were active and foraging during May 2013 by walking through the habitat and hand capturing arthropods (beetles, ants, termites and spiders) and sweeping vegetation with a net (flies, bees, wasps, true bugs, as well as some beetles and spiders). We made a concerted effort to sample ants and termites (identified as key components of lizard diet; Murray et al. 2016) in the same microhabitats where we saw lizards. Arthropods were kept cool (approximately $15^{\circ} \mathrm{C}$ ) in vials for $1-3$ days, a period in which we assumed that all gut contents were metabolized, and then frozen (approximately $-4^{\circ} \mathrm{C}$ ) for storage. We acknowledge the potential difficulties involved with inferring lizard consumption of arthropods in summer based on the tissue isotope ratios of arthropods collected during late autumn/early winter. However, for the primary prey items that lizards feed on, such as termites and ants, the long periods of time required for growth and development means that any diet switches in those arthropods could take several months to be reflected in the arthropod tissue isotope ratios (termites [Watson 1973]; ants [Mooney \& Tillberg 2005; Straka \& Feldhaar 2007; Menke et al. 2010]). We identified arthropods to the species level where possible, and otherwise to the order, family or genus level, using references for southern African arthropods (Scholtz \& Holm 1985; Marsh 1986; Uys 2002; Picker et al. 2004). As with plant samples, we dried arthropods in an oven and homogenized individuals before loading them in 4 $\times 6$-mm tin capsules.

\section{Stable isotope analyses}

We analyzed all of our tissue samples for carbon $\left(\delta^{13} \mathrm{C}\right)$ and nitrogen $\left(\delta^{15} \mathrm{~N}\right)$ stable isotope ratios using a continuous flow isotope ratio mass spectrometer (Delta V Plus, ThermoFinnigan, Bremen, Germany) connected to an Elemental Analyzer (Flash EA 1112 series, ThermoFinnigan, Bremen, Germany) in the University of Pretoria Isotope Ratio Mass Spectrometry Laboratory. The instrumental precision of these measurements was $\pm 0.1 \%$ SD based on repeated measurements of internal laboratory standards. All sample runs included a laboratory standard (Merck Gel $\delta^{13} \mathrm{C}=-20.57 \%$; $\delta^{15} \mathrm{~N}=6.8 \%$ ) and blank after each set of 12 unknowns. Isotope concentrations are reported in delta notation $(\delta)$ in parts per thousand (\%): $\delta X=\left(R_{\text {sample }} / R_{\text {standard }}-1\right)$ $* 1000 . R_{\text {sample }}$ and $R_{\text {standard }}$ represent the ratio of heavy to light isotopes $\left({ }^{13} \mathrm{C} /{ }^{12} \mathrm{C}\right.$ or $\left.{ }^{15} \mathrm{~N} /{ }^{14} \mathrm{~N}\right)$ for the sample and standard. The results are normalized to the international standards air for $\delta^{15} \mathrm{~N}$ and Vienna Pee Dee Belemnite for $\delta^{13} \mathrm{C}$.

When carbon and nitrogen stable isotope ratios in consumer tissue are analyzed, there is often an offset between the diet and the tissue termed the diet-to-tissue discrimination factor $(\Delta)$. Diet-to-tissue discrimination factors may significantly differ according to diet quality, growth rates, tissue or species (Caut et al. 2008; Caut et al. 2009; Boecklen et al. 2011). Determining discrimination factors requires time and labor-intensive feeding trials, which have not been carried out for all species (Gannes et al. 1997; Martínez del Rio \& Carleton 2012). Consequently, we used the mean $\Delta \delta^{13} \mathrm{C}$ $(0.4 \%, 91$ studies $)$ and the mean $\Delta \delta^{15} \mathrm{~N}(2.3 \%$ o, 65 studies) determined for poikilotherm tissue diet-to-tissue discrimination factors during controlled feeding trials to adjust our lizard tissue $\delta^{13} \mathrm{C}$ and $\delta^{15} \mathrm{~N}$ values (McCutchan et al. 2003). We assumed that all lizard tissues analyzed would have similar discrimination factors.

\section{Data analyses: Tissue stable isotope ratios}


We tested for sex-related differences in tissue stable isotope ratios for both species using 2-sample $t$-tests. Plasma and RBC samples from individual lizards are not independent, so we used repeated measures linear mixed effects models to compare the carbon and nitrogen isotope ratios between species across seasons. We used an unstructured repeated covariance type, and modeled species, season and the species*season interaction as fixed effects and individual lizard as a random effect. We conducted post hoc comparisons using a Bonferroni correction. We used 2-sample $t$-tests to compare the seasonal incorporation of arthropods feeding on $\mathrm{C}_{4} /$ CAM plant resources by the two lizard species.

\section{Data analyses: Isotopic niche metrics}

To compare seasonal changes in lizard dietary niches (using different tissues to estimate seasonal dietary changes), we used the Stable Isotope Bayesian Ellipses in $\mathrm{R}$ (SIBER) package to calculate the standard ellipse area corrected for small sample sizes $\left(\mathrm{SEA}_{\mathrm{c}}\right)$ as well as the area of overlap for the summer, autumn and late autumn/early winter dietary niches (Jackson et al. 2011). $\mathrm{SEA}_{\mathrm{c}}$ is a proxy for the trophic niche, and is the bivariate standard deviation of the stable isotope ratios (e.g. carbon and nitrogen) characterizing a group of consumers; $\mathrm{SEA}_{\mathrm{c}}$ thus represents the core isotopic niche for each lizard species. We also describe the area of the convex hull (TA), and the associated Layman niche metrics estimating additional measurements of species niche structure calculated using the package Stable Isotope Analyses in R (SIAR), for comparative purposes. The TA (the smallest surface that encompasses all of the carbon and nitrogen stable isotope ratios for individuals of a species in a bivariate plot) is a geometric approach that may be used to estimate consumer dietary niche breadth, although TA is more sensitive to sample size than $\mathrm{SEA}_{c}$, and fails to take into account uncertainty within a dataset (Layman et al. 2007; Parnell et al. 2010; Jackson et al. 2011). Layman niche metrics further characterize diet spacing patterns between individuals in a population, and include the mean distance to centroid (CD), the mean nearest neighbor distance (MNND) and the standard deviation of the mean nearest neighbor distance (SDNND; Layman et al. 2007). For example, high values of MNND would indicate a more diverse trophic niche, while high SDNND indicates a high degree of unevenness in the spacing of the individual lizards in bivariate isotopic space (Layman et al. 2007).

\section{Data analyses: Mixing models}

We estimated the extent to which lizards used arthropods dependent on $\mathrm{C}_{4} / \mathrm{CAM}$ versus $\mathrm{C}_{3}$ plant resources with a 2-end-point mixing model (Martínez del Rio \& Wolf 2005):

$$
\delta^{13} C_{(\text {tissue })}=p\left(\delta^{13} C_{(C 4 / C A M)}\right)+(1-p)\left(\delta^{13} C_{(C 3)}\right)+\Delta ; \quad .
$$

where "tissue" is either lizard plasma, whole blood or $\mathrm{RBC} ; p$ is the fraction of $\mathrm{C}_{4} / \mathrm{CAM}$ plant resources assimilated in lizard tissue; and $\mathrm{D}$ is the carbon discrimination factor (0.4\%, McCutchan et al. 2003). The subscripts " $C_{3}$ " and " $C_{4} / C A M$ " represent the carbon isotope ratios of $\mathrm{C}_{3}$ and $\mathrm{C}_{4} / \mathrm{CAM}$ plant photosynthetic pathways, respectively.

We estimated the proportional contribution of arthropod prey groups to lizard tissues using the Bayesian Stable Isotope Sourcing Using Sampling (SISUS; Erhardt \& Bedrick 2013) software which provides a significant advantage over other stable isotope mixing models because SISUS allows for the variability of stable isotope ratios in diet categories, as well as accounts for uncertainty in stable isotope discrimination factors (Erhardt \& Bedrick 2013). We identified potential prey based on those groups that we have found previously in lizard fecal pellets (Murray et al. 2016). We used SigmaPlot 8.0 (Systat Software, San Jose, CA, USA), Microsoft Excel 2007 (Microsoft, Redmond, WA, USA), IBM SPSS 21.0 (SPSS, Chicago, IL, USA) and R 2.15.2 (R Development Core Team 2009) for all analyses. For all analyses, significance was accepted at $P<0.05$ and values are reported as mean \pm SD.

\section{Results}

$\mathrm{C}_{3}$ plants and $\mathrm{C}_{4} / \mathrm{CAM}$ plants growing on the site had non-overlapping carbon isotope ratios, a critical observation allowing the sources of the nutrients assimilated by insectivorous lizards to be traced back to the plant functional groups consumed by their prey (Fig. 1). Mean carbon isotope ratios were $-26.2 \%$ $0.4 \%$ (range, $-30.3 \%$ to $-23.7 \%$; $n=16$ species) in $\mathrm{C}_{3}$ plant tissues and $-14.5 \%$ $\pm 0.3 \%$ o (range, $-16.4 \%$ to $-13.0 \% ; n=14$ species) in $\mathrm{C}_{4} / \mathrm{CAM}$ plant tissues. Plant tissue nitrogen ratios were $12.0 \% \pm \pm 1.0 \%$ in $\mathrm{C}_{3}$ plants (range, $7.4 \%$ to $18.4 \%$ ) and $10.4 \%$ $\pm 0.9 \%$ in $\mathrm{C}_{4} / \mathrm{CAM}$ plants (range, $6.8 \%$ to $19.3 \%$ ). 
Figure 1 Mean $( \pm \mathrm{SD}) \delta^{15} \mathrm{~N}$ and $\delta^{13} \mathrm{C}$ ratios for seasonal diet as estimated from plasma (late autumn/early winter), whole blood (WB; summer) and RBC (autumn) from the Husab sand lizard (Pehu, Pedioplanis husabensis) and Bradfield's Namib day gecko (Rhbr, Rhoptropus bradfieldi). Blood tissue carbon and nitrogen isotope ratios are plotted relative to the $\delta^{15} \mathrm{~N}$ and $\delta^{13} \mathrm{C}$ tissue values for individual species of plants belonging to different functional groups (30 species; $\mathrm{C}_{3}$ shrubs/trees, $\mathrm{C}_{4}$ grasses, $\mathrm{C}_{4}$ shrubs and crassulacean acid metabolism [CAM] succulents) available on the site. Lizard blood tissue $\delta^{15} \mathrm{~N}(2.3 \%$ ) and $\delta^{13} \mathrm{C}(0.4 \%)$ ratios have been adjusted by subtracting the appropriate diet-tissuediscrimination factors determined for poikilotherms (McCutchan et al. 2003).

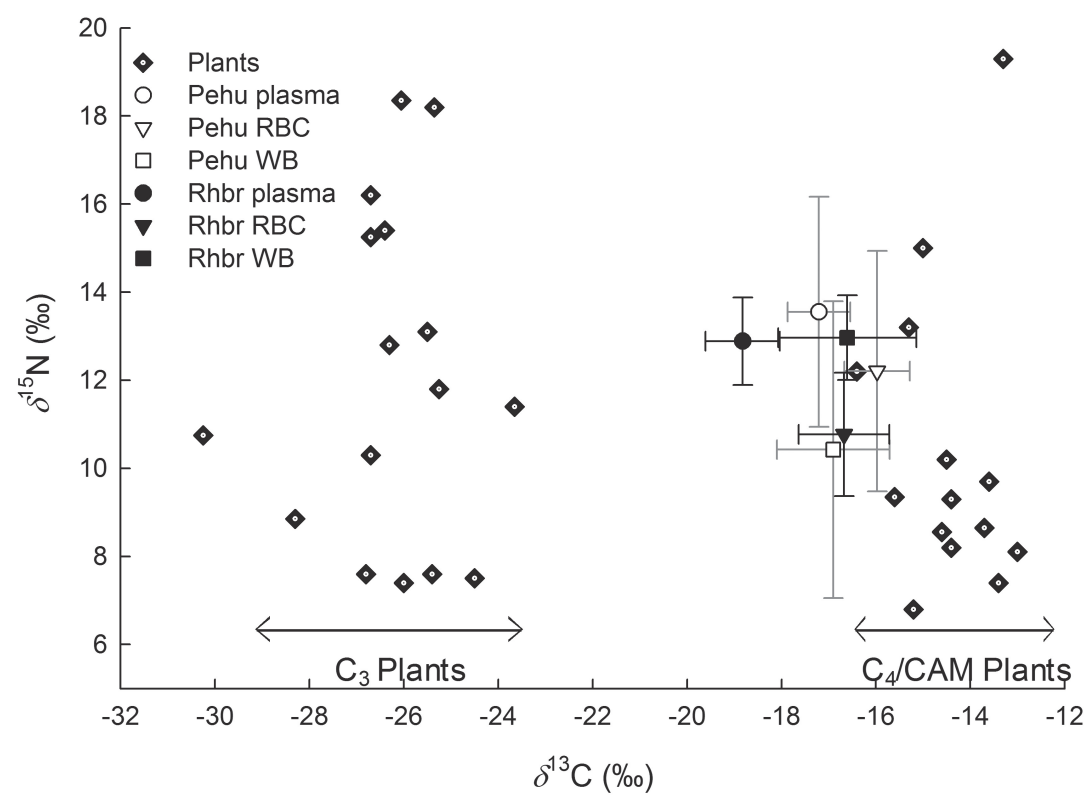

Table 1 Mean $( \pm \mathrm{SD}) \delta^{15} \mathrm{~N}$ and $\delta^{13} \mathrm{C}$ ratios of potential prey items collected during May 2013 for the Husab sand lizard (Pedioplanis husabensis) and Bradfield's Namib day gecko (Rhoptropus bradfieldi) along the dry Swakop River bed in the Namib Desert, Namibia

\begin{tabular}{|c|c|c|c|}
\hline Prey category & $n$ & Mean $\delta^{13} \mathrm{C}(\%)$ & Mean $\delta^{15} \mathrm{~N}(\%)$ \\
\hline \multicolumn{4}{|l|}{ Arachnida } \\
\hline Araneae & 12 & $-17.9 \pm 2.3$ & $18.3 \pm 2.4$ \\
\hline \multicolumn{4}{|l|}{ Insecta } \\
\hline \multicolumn{4}{|l|}{ Coleoptera } \\
\hline Psammodes/Physosterna/Zophosis/Scarabidae (beetles1) & 14 & $-14.9 \pm 1.9$ & $17.2 \pm 3.8$ \\
\hline Somaticus/Gonocephalum/Stenocara (beetles2) & 19 & $-20.1 \pm 3.2$ & $15.2 \pm 3.4$ \\
\hline Hemiptera & 2 & $-21.9 \pm 0.9$ & $13.4 \pm 3.3$ \\
\hline \multicolumn{4}{|l|}{ Hymenoptera } \\
\hline \multicolumn{4}{|l|}{ Ants } \\
\hline Lepisiota capensis & 4 & $-19.5 \pm 2.2$ & $16.7 \pm 1.6$ \\
\hline Pheidole sp. & 3 & $-15.3 \pm 0.3$ & $14.9 \pm 0.1$ \\
\hline Camponotus sp. & 2 & $-13.3 \pm 0.3$ & $14.5 \pm 1.5$ \\
\hline Bees & 4 & $-17.8 \pm 4.6$ & $14.8 \pm 3.9$ \\
\hline Wasps & 3 & $-18.7 \pm 5.0$ & $8.8 \pm 3.6$ \\
\hline \multicolumn{4}{|l|}{ Isoptera } \\
\hline Trinervitermes sp. & 6 & $-17.1 \pm 0.3$ & $5.8 \pm 0.2$ \\
\hline Hodotermes mossambicus & 8 & $-18.6 \pm 0.5$ & $7.3 \pm 0.6$ \\
\hline Psammotermes allocerus/Amitermes sp. & 16 & $-16.1 \pm 0.8$ & $11.8 \pm 1.0$ \\
\hline
\end{tabular}

Based on similar tissue isotope ratios the beetle genera Somaticus, Gonocephalum and Stenocara were combined into the category "beetles2," and the genera Psammodes, Physosterna, Zophosis and Scarabidae were combined into the category "beetles1." Sample sizes $(n)$ indicate the numbers of individuals sampled with the exception of the small ant Lepisiota capensis in which case each sample was a homogenate of 4 individual ants from a single nest. 
The potential arthropod prey groups of lizards occupied largely non-overlapping domains in carbon and nitrogen isotope niche space (Table 1). For example, mean $\delta^{13} \mathrm{C}$ ranged from $-21.9 \%$ o $\pm 0.9 \%$ in hemipteran insects to $-13.3 \% \pm 0.3 \%$ in ants in the genus Camponotus (Table 1). Arthropod prey groups also occupied a diversity of trophic levels, as evidenced by their tissue $\delta^{15} \mathrm{~N}$, which ranged from $18.3 \% \pm \pm 2.4 \%$ in spiders to $5.8 \% \pm 0.2 \%$ in termites of the genus Trinervitermes. There also was significant variation in tissue nitrogen and carbon isotope ratios for different arthropod genera within the same order, apparent, for example, in the distinct and non-overlapping $\delta^{13} \mathrm{C}$ and $\delta^{15} \mathrm{~N}$ ratios for genera of termites and ants (Table 1). The distinct isotope ratios of the lizards' potential prey allowed unambiguous identification of their diets.

There were no sex-related differences in blood carbon and nitrogen isotope ratios for both $P$. husabensis (RBC $\delta^{15} \mathrm{~N}, t_{41}=-0.22 ; P=0.829 ; \operatorname{RBC~} \delta^{13} \mathrm{C}, t_{41}=-0.55$; $P=0.582$; plasma $\delta^{15} \mathrm{~N}, t_{21}=0.32 ; P=0.752$; plasma $\delta^{13} \mathrm{C}, t_{23}=0.49 ; P=0.631$; whole blood $\delta^{15} \mathrm{~N}, t_{5}=1.98$; $P=0.105$; whole blood $\left.\delta^{13} \mathrm{C}, t_{6}=1.39 ; P=0.215\right)$ and $R$. bradfieldi $\left(\mathrm{RBC} \delta^{15} \mathrm{~N}, t_{12}=-0.01 ; P=0.996 ; \mathrm{RBC}\right.$ $\delta^{13} \mathrm{C}, t_{14}=-1.89 ; P=0.08$; plasma $\delta^{15} \mathrm{~N}, t_{7}=-1.63$; $P=0.148$; plasma $\delta^{13} \mathrm{C}, t_{15}=0.10 ; P=0.920$; whole blood $\delta^{15} \mathrm{~N}, t_{18}=-0.3 ; P=0.767$; whole blood $\delta^{13} \mathrm{C}, t_{10}$ $=-1.25 ; P=0.238$ ), so we combined male and female values for both species (Table 2). On average blood $\delta^{15} \mathrm{~N}$ did not differ between lizard species $\left(F_{1,82.091}=\right.$ $0.009 ; P=0.925)$, but there was a significant difference between seasons $\left(F_{2,67.392}=21.170 ; P=0.000\right)$ with the $\delta^{15} \mathrm{~N}$ ratio reflecting the late autumn/early winter dietary niche (plasma) significantly higher than those reflecting autumn (RBC) but not summer (whole blood) dietary niches. The interaction between species and season also was significant $\left(F_{2,67.392}=6.554 ; P=0.003\right.$; Table 2$)$. Across seasons the tissue $\delta^{15} \mathrm{~N}$ ratios increased similarly for $P$. husabensis, while for $R$. bradfieldi the $\delta^{15} \mathrm{~N}$ ratios were similar in summer and late autumn/early winter but declined in the autumn dietary niche (Table 2).

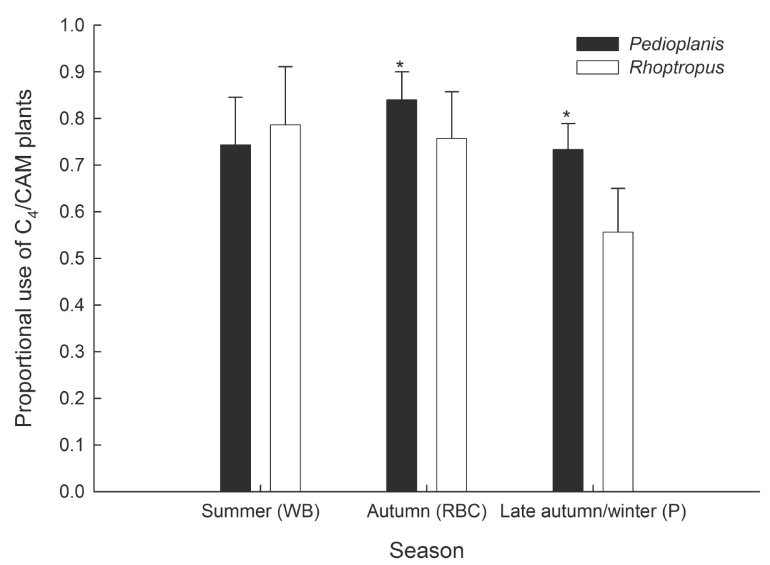

Figure 2 Mean $( \pm \mathrm{SD})$ proportional use of $\mathrm{C}_{4} /$ crassulacean acid metabolism [CAM] plant-derived resources, relative to $\mathrm{C}_{3}$ resources, as estimated from the $\delta^{13} \mathrm{C}$ ratios for the summer (WB, whole blood), autumn (RBC, red blood cells) and late autumn/early winter ( $\mathrm{P}$, plasma) tissue $\delta^{13} \mathrm{C}$ ratios from the Husab sand lizard (Pedioplanis husabensis) and Bradfield's Namib day gecko (Rhoptropus bradfieldi). ${ }^{*} P<0.001$; 2 -sample $t$-test for seasonal species differences in resource use.

Table 2 Mean $( \pm \mathrm{SD}) \delta^{15} \mathrm{~N}$ and $\delta^{13} \mathrm{C}$ ratios for austral summer dietary niches (November-January as estimated from whole blood), autumn dietary niches (March-May as estimated from red blood cells), and late autumn/early winter dietary niches (April-May, as estimated from plasma) for the Husab sand lizard (Pedioplanis husabensis) and Bradfield's Namib day gecko (Rhoptropus bradfieldi)

\begin{tabular}{lllllll}
\hline Isotope ratio & Summer & \multicolumn{3}{c}{ Lutumn } & \multicolumn{3}{l}{ Late autumn/early winter } \\
\hline & $\begin{array}{l}\text { Pedioplanis } \\
\text { husabensis }\end{array}$ & $\begin{array}{l}\text { Rhoptropus } \\
\text { bradfieldi }\end{array}$ & $\begin{array}{l}\text { Pedioplanis } \\
\text { husabensis }\end{array}$ & $\begin{array}{l}\text { Rhoptropus } \\
\text { bradfieldi }\end{array}$ & $\begin{array}{l}\text { Pedioplanis } \\
\text { husabensis }\end{array}$ & $\begin{array}{l}\text { Rhoptropus } \\
\text { bradfieldi }\end{array}$ \\
Mean $\delta^{13} \mathrm{C}(\%)$ & $-17.0 \pm 1.2$ & $-16.7 \pm 1.5$ & $-16.0 \pm 0.7$ & $-16.9 \pm 1.2 *$ & $-17.3 \pm 0.7$ & $-19.4 \pm 1.1^{*}$ \\
& $(n=27)$ & $(n=21)$ & $(n=43)$ & $(n=16)$ & $(n=39)$ & $(n=17)$ \\
Mean $\delta^{15} \mathrm{~N}(\%)$ & $10.8 \pm 2.7$ & $13.0 \pm 1.0^{*}$ & $12.2 \pm 2.7$ & $10.9 \pm 1.4$ & $13.5 \pm 2.7$ & $12.6 \pm 1.0$ \\
& $(n=26)$ & $(n=21)$ & $(n=43)$ & $(n=14)$ & $(n=39)$ & $(n=12)$ \\
\hline
\end{tabular}

Sample sizes $(n)$ indicate the number of individual lizards from which samples were analyzed. *Significant inter-species difference ( $95 \%$ confidence interval estimates; $P<0.05$ ). 
Blood $\delta^{13} \mathrm{C}$ ratios were on average significantly lower in $R$. bradfieldi than in $P$. husabensis $\left(F_{1,103.760}=\right.$ 21.494; $P<0.001)$. In addition, $\delta^{13} \mathrm{C}$ ratios reflecting late autumn/early winter diet (plasma) were significantly lower than the $\delta^{13} \mathrm{C}$ ratios reflecting both autumn (RBC) and summer (whole blood) diet $\left(F_{2,60.412}=161.763 ; P\right.$ $<0.001)$. The interaction between species and season again was significant $\left(F_{2,60.412}=23.812 ; P<0.001\right.$; Table 2). For $P$. husabensis, tissue $\delta^{13} \mathrm{C}$ ratios reflecting both the summer and late autumn/early winter dietary niches were lower than those reflecting the autumn dietary niche (Table 2). In $R$. bradfieldi the $\delta^{13} \mathrm{C}$ ratios remained the same for both the summer and autumn dietary niches, but were significantly lower for the late autumn/ early winter dietary niche (Table 2).

In addition to the species differences in seasonal dietary niches, $P$. husabensis assimilated significantly more nutrients from arthropods that fed primarily upon $\mathrm{C}_{4}$ or CAM plants than $R$. bradfieldi during autumn (2 sample $t$-test; $\left.t_{57}=3.91 ; P=0.000\right)$ and late autumn/ early winter ( 2 sample $t$-test; $t_{54}=8.78 ; P=0.000$ ) but not summer ( 2 sample $t$-test; $t_{46}=-1.30 ; P=0.201$; Fig. 2). During summer $R$. bradfieldi and $P$. husabensis both derived approximately $75 \%$ of their diet from arthropods that consumed $\mathrm{C}_{4} / \mathrm{CAM}$ plants. However, compared to $P$. husabensis, during autumn and late autumn/early winter $R$. bradfieldi sourced $10-20 \%$ fewer resources from arthropods feeding on $\mathrm{C}_{4} / \mathrm{CAM}$ plants (Fig. 2).

More evidence for the significant differences in the isotopic niches between $R$. bradfieldi and $P$. husabensis was that both the $\mathrm{SEA}_{\mathrm{c}}$ and TA of $P$. husabensis's dietary niche were larger than those of $R$. bradfieldi across all seasons (Table 3, Fig. 3). During the summer and late autumn/early winter, the dietary niche $\mathrm{SEA}_{\mathrm{c}}$ was more than twice that for $P$. husabensis than for $R$. bradfieldi, while during autumn $P$. husabensis's dietary niche was only slightly greater than that of $R$. bradfieldi (Table $3)$. There was also considerable seasonal overlap in the summer, autumn and late autumn/early winter $\mathrm{SEA}_{\mathrm{c}} \mathrm{s}$ for P. husabensis, while the dietary niche for $R$. bradfieldi was spatially distinct across these seasons (Fig. 3). The niches of the two species overlapped in summer such that the area of that overlap occupied approximately half of the total niche area in $R$. bradfieldi, but only one-fifth of $P$. husabensis's summer niche area (Table 3). During autumn, the overlap in the lizards' dietary niches took up a similar proportion of the total area of the autumn dietary niche in both species (Table 3). However, during late autumn/early winter there was almost no overlap in the dietary niches of $R$. bradfieldi and P. husabensis

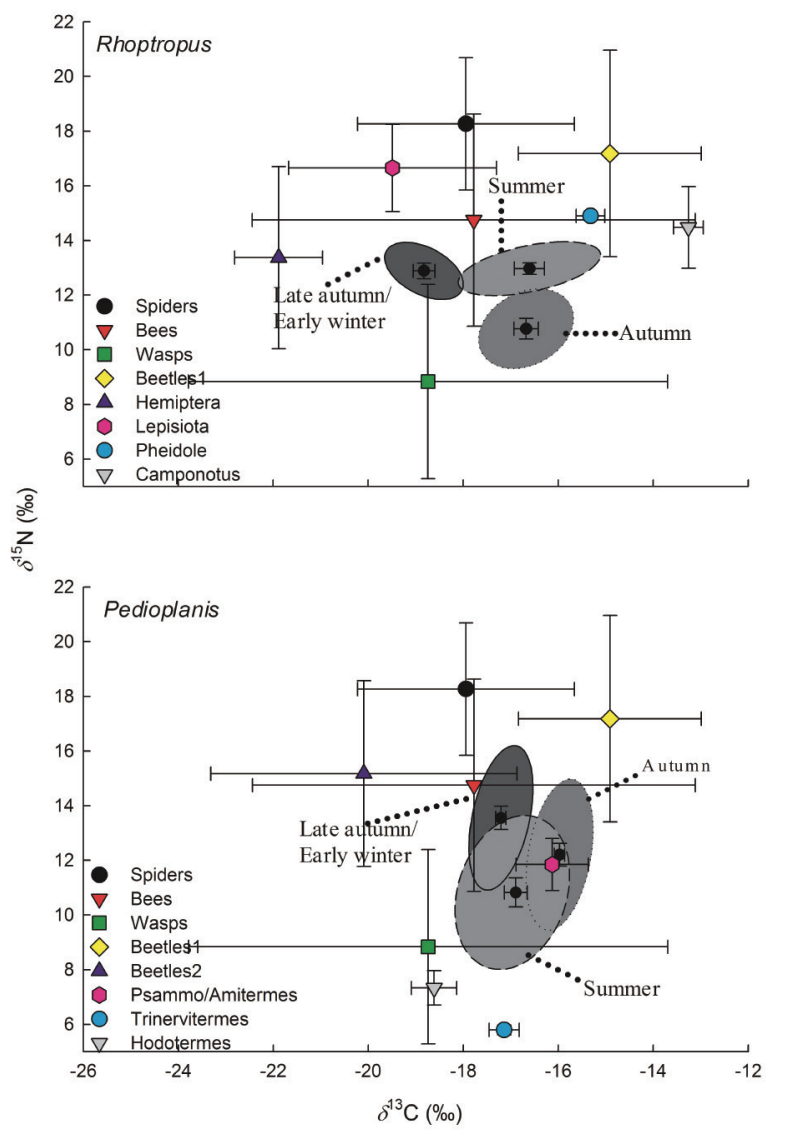

Figure 3 The distribution of the mean $( \pm \mathrm{SD}) \delta^{15} \mathrm{~N}$ and $\delta^{13} \mathrm{C}$ ratios for potential arthropod prey categories relative to the mean $( \pm \mathrm{SD})$ and the seasonal standard ellipse areas corrected for small sample sizes $\left(\mathrm{SEA}_{\mathrm{c}}\right.$ ) during summer (whole blood), autumn (red blood cells) and late autumn/early winter (plasma) for sympatric Bradfield's Namib day geckos, Rhoptropus bradfieldi (upper panel) and Husab sand lizards, Pedioplanis husabensis (lower panel). Lizard blood tissue $\delta^{15} \mathrm{~N}(2.3 \%$ ) and $\delta^{13} \mathrm{C}(0.4 \%)$ ratios have been adjusted by subtracting the appropriate diet-tissue-discrimination factors determined for poikilotherms in a recent meta-analysis (McCutchan et al. 2003).

(Table 3). Furthermore, in all seasons the CD was greater for $P$. husabensis relative to $R$. bradfieldi, while the MNND and SDNND were either similar in size or greater for $R$. bradfieldi compared to P. husabensis (Table 3).

Analysis of the whole blood isotope ratios indicated that the summer diet of $P$. husabensis was $63 \%$ termites, 
Table 3 Calculated niche metrics based on the $\delta^{15} \mathrm{~N}$ and $\delta^{13} \mathrm{C}$ ratios during austral summer as estimated from whole blood, austral autumn as estimated from red blood cells and austral late autumn/early winter as estimated from plasma in the Husab sand lizard (Pedioplanis husabensis) and Bradfield's Namib day gecko (Rhoptropus bradfieldi)

\begin{tabular}{|c|c|c|c|c|c|c|}
\hline \multirow[t]{2}{*}{ Niche metric } & \multicolumn{2}{|l|}{ Summer } & \multicolumn{2}{|l|}{ Autumn } & \multicolumn{2}{|c|}{ Late autumn/Early winter } \\
\hline & $\begin{array}{l}\text { Pedioplanis } \\
\text { husabensis }\end{array}$ & $\begin{array}{l}\text { Rhoptropus } \\
\text { bradfieldi }\end{array}$ & $\begin{array}{l}\text { Pedioplanis } \\
\text { husabensis }\end{array}$ & $\begin{array}{l}\text { Rhoptropus } \\
\text { bradfieldi }\end{array}$ & $\begin{array}{l}\text { Pedioplanis } \\
\text { husabensis }\end{array}$ & $\begin{array}{l}\text { Rhoptropus } \\
\text { bradfieldi }\end{array}$ \\
\hline \multicolumn{7}{|c|}{ Standard ellipse area } \\
\hline SEAc & 10.4 & 4.0 & 5.8 & 4.4 & 5.1 & 2.4 \\
\hline Area of overlap & 2.3 & & 2.0 & & 0 & \\
\hline \multicolumn{7}{|c|}{ Layman niche metrics } \\
\hline TA & 27.0 & 12.1 & 21.7 & 7.9 & 15.9 & 5.1 \\
\hline $\mathrm{CD}$ & 2.6 & 1.5 & 2.4 & 1.5 & 2.3 & 1.0 \\
\hline MNND & 0.73 & 0.63 & 0.44 & 0.59 & 0.35 & 0.58 \\
\hline SDNND & 0.43 & 0.54 & 0.29 & 0.38 & 0.18 & 0.38 \\
\hline
\end{tabular}

Niche metrics are based on standard ellipse areas corrected for small sample sizes $\left(\mathrm{SEA}_{\mathrm{c}}\right)$ and the inter-species overlap between seasonal $\mathrm{SEA}_{c}$, as well as the Layman niche metrics area of the convex hull (TA), distance to centroid (CD), mean nearest neighbor distance (MNND), and the standard deviation of the mean nearest neighbor distance (SDNND).

Table 4 The relative contribution of arthropod prey groups to the diet of sympatric Bradfield's Namib day geckos (Rhoptropus bradfieldi) and Husab sand lizards (Pedioplanis husabensis), as calculated (mean \pm SD) by the software Stable Isotope Sourcing Using Sampling (SISUS) using carbon and nitrogen isotopes

\begin{tabular}{|c|c|c|c|c|c|c|}
\hline \multirow[t]{2}{*}{ Prey category } & \multicolumn{2}{|l|}{$\begin{array}{l}\text { Summer } \\
\text { diet }\end{array}$} & \multicolumn{2}{|l|}{$\begin{array}{l}\text { Autumn } \\
\text { diet }\end{array}$} & \multicolumn{2}{|c|}{$\begin{array}{l}\text { Late autumn/early } \\
\text { winter diet }\end{array}$} \\
\hline & $\begin{array}{l}\text { Pedioplanis } \\
\text { husabensis }\end{array}$ & $\begin{array}{l}\text { Rhoptropus } \\
\text { bradfieldi }\end{array}$ & $\begin{array}{l}\text { Pedioplanis } \\
\text { husabensis }\end{array}$ & $\begin{array}{l}\text { Rhoptropus } \\
\text { bradfieldi }\end{array}$ & $\begin{array}{l}\text { Pedioplanis } \\
\text { husabensis }\end{array}$ & $\begin{array}{l}\text { Rhoptropus } \\
\text { bradfieldi }\end{array}$ \\
\hline \multicolumn{7}{|l|}{ Arachnida } \\
\hline Araneae & $0.05 \pm 0.04$ & $0.04 \pm 0.03$ & $0.01 \pm 0.01$ & $0.01 \pm 0.01$ & $0.16 \pm 0.10$ & $0.05 \pm 0.04$ \\
\hline \multicolumn{7}{|l|}{ Insecta } \\
\hline \multicolumn{7}{|l|}{ Coleoptera } \\
\hline $\begin{array}{l}\text { Psammodes/Physosterna/Zophosis/ } \\
\text { Scarabidae (beetles } 1 \text { ) }\end{array}$ & $0.15 \pm 0.08$ & $0.07 \pm 0.06$ & $0.44 \pm 0.07$ & $0.01 \pm 0.01$ & $0.19 \pm 0.08$ & $0.04 \pm 0.03$ \\
\hline $\begin{array}{l}\text { Somaticus/Gonocephalum/Stenocara } \\
\text { (beetles2) }\end{array}$ & $0.08 \pm 0.06$ & - & $0.01 \pm 0.01$ & - & $0.09 \pm 0.07$ & - \\
\hline Hemiptera & - & $0.05 \pm 0.04$ & - & - & - & $0.40 \pm 0.07$ \\
\hline \multicolumn{7}{|l|}{ Hymenoptera } \\
\hline \multicolumn{7}{|l|}{ Ants } \\
\hline Camponotus sp. & - & $0.21 \pm 0.10$ & - & $0.29 \pm 0.01$ & - & $0.04 \pm 0.03$ \\
\hline Pheidole sp. & - & $0.13 \pm 0.10$ & - & $0.01 \pm 0.01$ & - & $0.05 \pm 0.04$ \\
\hline Lepisiota capensis & - & $0.04 \pm 0.03$ & - & - & - & $0.08 \pm 0.06$ \\
\hline Bees & $0.06 \pm 0.05$ & $0.07 \pm 0.06$ & $0.01 \pm 0.01$ & $0.01 \pm 0.01$ & $0.16 \pm 0.13$ & $0.07 \pm 0.06$ \\
\hline Wasps & $0.08 \pm 0.06$ & $0.35 \pm 0.04$ & $0.01 \pm 0.01$ & $0.67 \pm 0.01$ & $0.08 \pm 0.06$ & $0.29 \pm 0.04$ \\
\hline \multicolumn{7}{|l|}{ Isoptera } \\
\hline Trinervitermes sp. & $0.29 \pm 0.10$ & - & $0.32 \pm 0.07$ & - & $0.08 \pm 0.06$ & - \\
\hline $\begin{array}{l}\text { Psammotermes allocerus/Amitermes } \\
\text { sp. }\end{array}$ & $0.25 \pm 0.16$ & - & $0.18 \pm 0.16$ & - & $0.15 \pm 0.10$ & - \\
\hline Hodotermes mossambicus & $0.09 \pm 0.07$ & - & $0.02 \pm 0.01$ & - & $0.08 \pm 0.06$ & - \\
\hline
\end{tabular}

- , not included in the diet, based upon prior gut content analyses (Murray et al. 2016). 
wasps, $17 \%$ ants and $7 \%$ bees) but with considerable contributions from hemipterans $(40 \%)$ and a low proportion of spiders and beetles (Table 4).

\section{Discussion}

The insectivorous lizards $P$. husabensis and $R$. bradfieldi occurred within an isotopically-diverse landscape of $\mathrm{C}_{3}$ and $\mathrm{C}_{4} / \mathrm{CAM}$ plants (Fig. 1), and, consequently, had an isotopically-distinct prey base of arthropods available to them (Table 1). That isotopic diversity allowed us to assess changes in lizard resource use over time. There was considerable variation between the two species in arthropod resource use (Fig. 3, Table 4). Although both lizard species showed some degree of seasonal variation in arthropod prey use, the dietary composition of the two lizard species did not overlap in its major constituents (Table 4). P. husabensis fed predominantly on termites and beetles, while $R$. bradfieldi fed predominantly on ants, wasps and hemipteran insects. Furthermore, despite the presence of considerable $\mathrm{C}_{3}$ plant biomass in their immediate habitat, these two insectivorous lizard species showed a preference for arthropods dependent on $\mathrm{C}_{4} / \mathrm{CAM}$ plants (Fig. 2).

Overall, the $\delta^{15} \mathrm{~N}$ ratios for lizard tissues were similar, implying that $R$. bradfieldi and $P$. husabensis fed at the same trophic level, although the lower $\delta^{15} \mathrm{~N}$ ratios for $P$. husabensis in summer may reflect its high consumption of termites with their relatively low tissue $\delta^{15} \mathrm{~N}$ ratios at this time of year. However, when we examined $\delta^{15} \mathrm{~N}$ values in conjunction with $\delta^{13} \mathrm{C}$ values seasonally, we found notable differences between $P$. husabensis's and $R$. bradfieldi's dietary niche (Table 2). For example, $P$. husabensis always had a larger dietary niche (TA and $\mathrm{SEA}_{\mathrm{c}}$ ) than did $R$. bradfieldi occupying the same habitat (Fig. 3; Table 3). Depending on the season, the TA of P. husabensis was 2.2-3.1 times larger than the corresponding TA in $R$. bradfieldi. The TA incorporates data from all individuals, including outliers that may be critical to capturing the population's or species' complete trophic spectrum (Layman et al. 2012); however, it is a metric that is sensitive to sample size (Jackson et al. 2011), and we sampled fewer $R$. bradfieldi than P. husabensis (Table 2). The $\mathrm{SEA}_{\mathrm{c}}$ is a metric which characterizes the niche far more robustly given a limited sample size, and the $\mathrm{SEA}_{\mathrm{c}}$ results echoed those yielded from the TA analysis: $\mathrm{SEA}_{\mathrm{c}}$ for P. husabensis was 1.32.6 times larger than that of $R$. bradfieldi (Table 3). In addition to having a larger isotopic niche, there was a higher degree of trophic diversity among individual $P$. husabensis relative to $R$. bradfieldi, as evidenced by the higher CD (Table 3), but the higher SDNND and MNND for $R$. bradfieldi in autumn and late autumn/ early winter indicated that individuals of this species had less redundancy in the trophic niche than did individuals of $P$. husabensis (Layman et al. 2007; Table $3)$. These niche differences reflect the consumption of distinct arthropod prey items and probably result from differences in foraging strategies between the two lizard species.

Pedioplanis husabensis uses an active foraging strategy and moves widely through its habitat (Murray et al. 2014). In contrast, $R$. bradfieldi uses a sit-and-wait foraging strategy in which it ambushes its prey from an immobile and exposed position (Murray et al. 2015). Relative to sit-and-wait foraging lizards, activelyforaging lizards are likely to have larger territories and move over greater distances through a diversity of habitats (Pianka 1986; Vitt et al. 2003). While we lack data on home range size and the spatial length of daily movements in $P$. husabensis and $R$. bradfieldi, data from other communities of insectivorous desert lizards indicate that the hourly distances moved by active foraging lizards are 4 to 4.5 times the distances (Anderson \& Karasov 1981; Huey \& Pianka 1981) and the home ranges 4 times larger (Anderson \& Karasov 1981) than those of sympatric sit-and-wait foraging lizards. As lizards forage over greater distances they are likely to encounter a greater degree of habitat heterogeneity. Because landscape heterogeneity is positively correlated with arthropod diversity (Liu et al. 2013), it is likely that more widely foraging lizards may come into contact with a more diverse assortment of prey and, thus, have a larger trophic niche, as we found for $P$. husabensis. Because actively-foraging lizards use visual and chemosensory means to locate prey above and below ground, they are also capable of feeding on a greater array of potential prey, such as subterranean insect larvae and immobile insect pupae that are not available to sit-and-wait foraging lizards (Pianka 1986; Vitt et al. 2003). Therefore, the consequences of foraging actively may contribute to the larger trophic niche of $P$. husabensis.

Compared to P. husabensis, the variable and non-overlapping seasonal $\mathrm{SEA}_{\mathrm{c}} \mathrm{s}$ for $R$. bradfieldi may be related to a sit-and-wait predator foraging opportunistically during a particular time of year (Fig. $3)$. The reduced trophic redundancy and increased "unevenness" characterizing $R$. bradfieldi in isotopic 
space during autumn and late autumn/early winter (high MNND and SDNND; Table 3) implies that $R$. bradfieldi show a less uniform pattern of resource use. This pattern could be due to individual geckos encountering a relatively heterogeneous variety of arthropods during sit-and-wait foraging bouts. In contrast, individuals of the actively-foraging $P$. husabensis can target distinct prey resources, specifically making its dietary niche more uniform. We acknowledge that we cannot be sure that the isotopically-distinct $\mathrm{SEA}_{\mathrm{c}}$ found seasonally for $R$. bradfieldi are the result of the inclusion of different types of arthropod prey in the diet; the diets of the arthropods themselves may have varied seasonally, and we did not collect arthropod samples during summer. Further data collection would be required to better address this question.

From the perspective of individual consumers, the relative importance of the $\mathrm{C}_{3}$ versus $\mathrm{C}_{4}$ components of plant primary productivity varies by species, season and habitat (Magnusson et al. 1999; Warne et al. 2010a). In addition, $C_{4}$ plant production represents an important component of food web nutrients, particularly in arid ecosystems (Ehleringer et al. 1997; Still et al. 2003). There are relatively few studies estimating the transfer of $\mathrm{C}_{3}$ versus $\mathrm{C}_{4}$-derived nutrients to higherlevel consumers, such as lizards in a nutritional landscape containing both $\mathrm{C}_{3}$ and $\mathrm{C}_{4}$ plants (Magnusson et al. 1999, 2001; Warne et al. 2010a). However, the available data indicate that lizards continue to acquire considerable amounts of nutrients from prey that feed on $\mathrm{C}_{3}$ plant resources even when appreciable proportions of total primary productivity stem from $\mathrm{C}_{4}$ plants (Magnusson et al. 1999, 2001; Smith et al. 2002; Warne et al. 2010a). However, contrary to other published studies, our lizards included a large proportion of arthropods that consumed resources derived from $\mathrm{C}_{4} /$ CAM plants.

While we cannot distinguish between the carbon isotope ratios of $\mathrm{C}_{4}$ and CAM plants on our study site, CAM plants were a minor component of the landscape and were represented chiefly by scattered and isolated succulents, while perennial and annual $\mathrm{C}_{4}$ grasses and the $\mathrm{C}_{4}$ shrub Salsola sp. were conspicuous and regular components of the landscape (I Murray, personal observation). Some Namib Desert plants are capable of facultatively switching between $\mathrm{C}_{3}$ and CAM photosynthesis depending on water stress (e.g. Winter et al. 1978), and insect use of these resources could lead to a misinterpretation of insectivore use of plant resources based on tissue stable isotope ratios. However, these plants were relatively minor components of the local flora (e.g. Mesembryanthemum guericheanum; represented by several widely scattered small individuals). Consequently, an enriched carbon isotope ratio in insectivores here is likely to represent significant use of $\mathrm{C}_{4}$ plants.

Pedioplanis husabensis obtained more than $70 \%$ of its nutrients from arthropods that sourced most of their carbon from $\mathrm{C}_{4}$ plants in all seasons that we studied, as did R. bradfieldi in summer and autumn. During late autumn/early winter, however, $R$. bradfieldi preyed almost equally on arthropods dependent on $\mathrm{C}_{3}$ plants (Fig. 2). For P. husabensis, we believe that its consumption of termites brought about its tight linkage to $\mathrm{C}_{4}$ plants. The termite genera that it fed upon are known to feed largely on $\mathrm{C}_{4}$ grasses (e.g. Hodotermes, Psammotermes and Trinervitermes; De Visser et al. 2008; Symes \& Woodborne 2011), and our carbon isotope analyses of individual termites supported this assertion (Table 1). However, we are unable to distinguish isotopically between termites feeding on $\mathrm{C}_{4}$ grasses and on woody $\mathrm{C}_{4}$ shrubs such Salsola sp. that occurred on the site, which means that the importance of $\mathrm{C}_{4}$ grasses to the arthropods making up $P$. husabensis's dietary niche may be overestimated. In an entirely different system, consumption of termites also was considered to underlie flow of $\mathrm{C}_{4}$ grass-derived nutrients into lizard and frog tissues (Magnusson et al. 1999, 2001).

Compared to P. husabensis, $R$. bradfieldi fed to a greater extent on arthropods that used $\mathrm{C}_{3}$ plant biomass (Figs. 2 and 3). During late autumn/early winter in particular, $R$. bradfieldi acquired nutrients from arthropods that used significantly more $\mathrm{C}_{3}$ plantderived resources than $\operatorname{did} P$. husabensis, incorporating up to $54 \%$ of its carbon from $\mathrm{C}_{3}$ plant resources (Fig. 2 ). We surmise that the late autumn/early winter dietary niche of $R$. bradfieldi reflected incorporation of arthropods using $\mathrm{C}_{3}$ plant production available after recent precipitation (Noy-Meir 1973, 1974; Polis 1997). As a sit-and-wait forager $R$. bradfieldi is likely to feed largely on more mobile arthropods that are active during its diurnal activity period (Pianka 1986). Indeed, the SISUS mixing model results showed its diet to be made up of mobile and diurnally-active insects like ants, wasps and hemipterans (Table 4). The ecology of these arthropod groups also enables them to transfer this $\mathrm{C}_{3}$ plant biomass to $R$. bradfieldi effectively. For example, 
hemipterans make up a large part of the total available arthropod biomass after rare desert precipitation events (Polis 1991), and many small wasps feed on $C_{3}$ flower pollen or are predators on insects that feed on $\mathrm{C}_{3}$ plant production (Scholtz \& Holm 1985; Picker et al. 2004).

Our previous work documenting the diet of $P$. husabensis and R. bradfieldi during May of 2013 using fecal pellet analyses generally supports our estimates of diet composition based on the SISUS mixing model results (Murray et al. 2016). These fecal pellet analyses showed that the diet of $P$. husabensis was dominated numerically by termites $(71 \%)$ and that of $R$. bradfieldi by ants ( $87 \%$; Murray et al. 2016). However, we note that the mixing model results and the fecal pellet analyses do not align perfectly such that, in some seasons, $P$. husabensis and $R$. bradfieldi incorporated fewer nutrients from termites and ants than the fecal pellet analysis implied (Table 4). These contrasting results are perhaps not surprising given the very short periods over which fecal pellet analyses survey diet (days) relative to the period over which the mixing model results based on body tissues do (1-2 months), as well as the fact that the fecal pellet diet analyses estimated prey items and not proportional contribution to diet. We further acknowledge that diet reconstructions estimated from isotope mixing models may give false-positive results even if the items are not included in the diet and it may be difficult to include coverage of all possible dietary items. In addition, here we have employed blood only, and left unexplored the differential routing of prey macronutrients and their associated stable isotope ratios to different tissues (Podlesak et al. 2006; Voigt et al. 2008).

Recent models imply that climate change in the Namib Desert could result in a mean annual increase of up to $3{ }^{\circ} \mathrm{C}$ and a reduction in annual precipitation by up to $22 \%$, with coastal regions of the Namib Desert likely experiencing less pronounced change (Thuiller et al. 2006). In this xeric environment the potential benefits that increased atmospheric $\mathrm{CO}_{2}$ levels may have for plant photosynthetic efficiency elsewhere are not likely to be capable of compensating for warmer and drier conditions. $\mathrm{C}_{3}$ plant biomass is projected to decrease significantly in parts of the Namib Desert, while $\mathrm{C}_{4}$ plant biomass is likely to change to a much lesser extent in the Namib Desert (Thuiller et al. 2006). However, modeling the impacts of climate change in the Namib Desert is made more complex due to the significant role that fog-derived moisture plays in this system (Henschel $\&$ Seely 2008). The number of days that fog occurs may increase slightly in the coastal Namib Desert, but decrease by $23-39 \%$ further inland (Haensler et al. 2011).

While we do not know how reliant on fog moisture versus precipitation the $\mathrm{C}_{4} / \mathrm{CAM}$ plants are that fed the arthropods that the lizards preyed on, most of the $\mathrm{C}_{3}$ plants in the dry riverbed are reliant upon ground water, and evidence exists suggesting that some riverbed trees (e.g. Vachellia erioloba and Faidherbia albida) may already be experiencing significant water stress from reduced ground water availability (Schachtschneider \& February 2010). Furthermore, most of the primary productivity on the gravel plains of the Namib Desert is from annual $\mathrm{C}_{4}$ grasses that grow in response to rainfall (Henschel et al. 2005). While the effects of reduced precipitation, warmer temperatures and higher atmospheric $\mathrm{CO}_{2}$ levels could potentially lead to losses of $\mathrm{C}_{4} / \mathrm{CAM}$ plant biomass and reductions in plant nutritional quality, lizards in this study occupy dry riverbed habitat at the juxtaposition of a $\mathrm{C}_{3}$ riparian woodland plant community and $\mathrm{C}_{4} / \mathrm{CAM}$ desert plant community. Their potential resource use flexibility, coupled with this habitat juxtaposition, may allow enhanced consumer resilience despite negative climate change impacts to particular plant groups.

We describe and compare the movement of nutrients from the $\mathrm{C}_{3}$ and $\mathrm{C}_{4} / \mathrm{CAM}$ photosynthetic pathways of primary productivity into two secondary consumers (lizards) in the Namib Desert. We show that two sympatric species of insectivores consume isotopically distinct arthropod resources, and that despite the very high available biomass of $\mathrm{C}_{3}$ plants in the adjacent riparian plant community, these two lizard species both rely heavily on a food web based on $\mathrm{C}_{4} / \mathrm{CAM}$-based plant resources. Although the amount of flexibility that these lizards and their arthropod prey have in their dietary ecology is unknown, we think it possible that any potential negative impacts that climate change may have on the availability or nutritional quality of $\mathrm{C}_{3}$ versus $\mathrm{C}_{4} / \mathrm{CAM}$ plants in this system may be partially buffered by the food web flexibility provided by the adjacent plant community types. Our findings highlight the importance of understanding how environmental change may impact different plant functional groups when considering ecosystem-level implications of climate change for consumer populations. Expanding the temporal, spatial and consumer scope of tissue stable isotope analyses may be particularly useful for better understanding food web dynamics in the Namib Desert. 


\section{Acknowledgments}

We thank Mary Seely, Theo Wassenaar and Gillian Maggs-Kölling of the Gobabeb Research and Training Centre in Namibia for critical research support and logistical help. We also thank Grant Hall of the University of Pretoria for assistance in the analysis of stable isotope samples, and Jonathan Clarke for assistance in the field. We are grateful to Antoinette and Walter Skutsch for accommodation at Hildenhof. Research funding was provided by an FRC individual grant to IWM from the University of the Witwatersrand's Faculty of Health Sciences and a National Research Foundation International Research Grant (Namibia/South Africa Research Cooperation Programme grant \# 89140) to DM and Gillian MaggsKölling. IWM acknowledges the support of the Claude Leon Foundation through postdoctoral fellowship funding.

\section{References}

Anderson RA, Karasov WH (1981). Contrasts in energy-intake and expenditure in sit-and-wait and widely foraging lizards. Oecologia 49, 67-72.

Barbehenn RV, Karowe DN, Chen Z (2004a). Performance of a generalist grasshopper on a C-3 and a C-4 grass: Compensation for the effects of elevated $\mathrm{CO}_{2}$ on plant nutritional quality. Oecologia 140, 96103.

Barbehenn RV, Karowe DN, Spickard A (2004b). Effects of elevated atmospheric $\mathrm{CO}_{2}$ on the nutritional ecology of C-3 and C-4 grass-feeding caterpillars. Oecologia 140, 86-95.

Bearhop S, Teece MA, Waldron S, Furness RW (2000). Influence of lipid and uric acid on $\delta^{13} \mathrm{C}$ and $\delta^{15} \mathrm{~N}$ values of avian blood: Implications for trophic studies. The Auk 117, 504-7.

Berger-Dell'Mour HAE, Mayer W (1989). On the parapatric existence of two species of the Pedioplanis undata group (Reptilia: Sauria: Lacertidae) in the central Namib Desert (Southwest Africa) with description of the new species Pedioplanis husabensis. Herpetozoa 1, 83-95.

Boecklen WJ, Yarnes CT, Cook BA, James AC (2011). On the use of stable isotopes in trophic ecology. Annual Review of Ecology, Evolution, and Systematics 42, 411-40.

Bond WJ, Midgley GF, Woodward FI (2003). The importance of low atmospheric $\mathrm{CO}_{2}$ and fire in promoting the spread of grasslands and savannas. Global Change Biology 9, 973-82.

Bowers MA, Brown JH (1982). Body size and coexistence in desert rodents: Chance or community structure? Ecology 63, 391-400.

Branch WR (1998). Field Guide to Snakes and Other Reptiles of Southern Africa. Struik, Cape Town.

Caut S, Angulo E, Courchamp F (2008). Caution on isotopic model use for analyses of consumer diet. Canadian Journal of Zoology 86, 438-45.

Caut S, Angulo E, Courchamp F (2009). Variation in discrimination factors $\left(\delta^{15} \mathrm{~N}\right.$ and $\left.\delta^{13} \mathrm{C}\right)$ : The effect of diet isotopic values and applications for diet reconstruction. Journal of Applied Ecology 46, 44353.

Cowlishaw G, Davies JG (1997). Flora of the ProNamib Desert Swakop River catchment, Namibia: Community classification and implications for desert vegetation sampling. Journal of Arid Environments 36, 271-90.

DeNiro MJ, Epstein S (1978). Influence of diet on the distribution of carbon isotopes in animals. Geochimica et Cosmochimica Acta 42, 495-506.

DeNiro MJ, Epstein S (1981). Influence of diet on the distribution of nitrogen isotopes in animals. Geochimica et Cosmochimica Acta 45, 341-51.

De Visser SA, Freymann BP, Schnyder H (2008). Trophic interactions among invertebrates in termitaria in the African savanna: A stable isotope approach. Ecological Entomology 33, 758-64.

Drake BG, Gonzàlez-Meler MA, Long SP (1997). More efficient plants: A consequence of rising atmospheric $\mathrm{CO}_{2}$ ? Annual Review of Plant Biology 48, 609-39.

Eckardt FD, Soderberg K, Coop LJ et al. (2013). The nature of moisture at Gobabeb, in the central Namib Desert. Journal of Arid Environments 93, 7-19.

Ehleringer JR, Rundel PW, Nagy KA (1986). Stable isotopes in physiological ecology and food web research. Trends in Ecology and Evolution 1, 42-5.

Ehleringer JR, Cerling TE, Helliker BR (1997). $C_{4}$ photosynthesis, atmospheric $\mathrm{CO}_{2}$ and climate. Oecologia 112, 285-99.

Ehleringer JR, Cerling TE, Dearing MD (2002). Atmospheric $\mathrm{CO}_{2}$ as a global change driver influencing plant-animal interactions. Integrative and Comparative Biology 42, 424-30.

Erhardt EB, Bedrick EJ (2013). A Bayesian framework for stable isotope mixing models. Environmental and Ecological Statistics 20, 377-97. 
Flaherty EA, Ben-David M, Smith WP (2010). Diet and food availability: Implications for foraging and dispersal of Prince of Wales northern flying squirrels across managed landscapes. Journal of Mammalogy 91, 79-91.

Futuyma DJ, Moreno G (1988). The evolution of ecological specialization. Annual Review of Ecology, Evolution, and Systematics 19, 207-33.

Gannes LZ, O’Brien DM, Martínez del Rio C (1997). Stable isotopes in animal ecology: Assumptions, caveats, and a call for more laboratory experiments. Ecology 78, 1271-6.

Haensler A, Cermak J, Hagemann S, Jacob D (2011). Will the southern African west coast fog be affected by future climate change? Results of an initial fog projection using a regional climate model. Erdkunde 2011, 261-75.

Hardin G (1960). The competitive exclusion principle. Science 131, 1292-7.

Henschel JR, Seely MK (2008). Ecophysiology of atmospheric moisture in the Namib Desert. Atmospheric Research 87, 362-8.

Henschel JR, Burke A, Seely M (2005). Temporal and spatial variability of grass productivity in the central Namib Desert. African Study Monographs 30, 43-56.

Herrmann HW, Branch WR (2013). Fifty years of herpetological research in the Namib Desert and Namibia with an updated and annotated species checklist. Journal of Arid Environments 93, 94-115.

Huey RB, Pianka ER (1981). Ecological consequences of foraging mode. Ecology 62, 991-9.

Hutchinson GE (1957). Population studies - animal ecology and demography - Concluding remarks. Cold Spring Harbor Symposia on Quantitative Biology 22, 415-27.

IPCC (2014). Climate Change 2014: Synthesis Report. Contribution of Working Groups I, II and III to the Fifth Assessment Report of the Intergovernmental Panel on Climate Change. Pachauri RK, Meyer LA, eds. IPCC, Geneva, Switzerland, $151 \mathrm{pp}$.

Jackson AL, Inger R, Parnell AC, Bearhop S (2011). Comparing isotopic niche widths among and within communities: SIBER - Stable Isotope Bayesian Ellipses in R. Journal of Animal Ecology 80, 595602.

Layman CA, Arrington DA, Montana CG, Post DM (2007). Can stable isotope ratios provide for community-wide measures of trophic structure? Ecology 88, 42-8.
Layman CA, Araújo MS, Boucek R et al. (2012). Applying stable isotopes to examine food web structure: an overview of analytical tools. Biological Reviews 87, 542-62.

Liu R, Zhu F, Song N, Yang X, Chai Y (2013). Seasonal distribution and diversity of ground arthropods in microhabitats following a shrub plantation age sequence in desertified steppe. PLOS ONE 8, e 77962.

MacArthur RH (1958). Population ecology of some warblers of northeastern coniferous forests. Ecology 39, 599-619.

MacArthur R, Levins R (1967). The limiting similarity, convergence, and divergence of coexisting species. American naturalist 101, 377-85.

Magnusson WE, de Araújo MC, Cintra R et al. (1999). Contributions of $\mathrm{C}_{3}$ and $\mathrm{C}_{4}$ plants to higher trophic levels in an Amazonian savanna. Oecologia 119, 916.

Magnusson WE, Lima AP, Faria AS, Victoria RL, Martinelli LA (2001). Size and carbon acquisition in lizards from Amazonian savanna: evidence from isotope analysis. Ecology 82, 1772-80.

Marsh AC (1986). Checklist, biological notes and distribution of ants in the central Namib Desert. Madoqua 14, 333-44.

Martínez del Rio C, Anderson-Sprecher R (2008). Beyond the reaction progress variable: the meaning and significance of isotopic incorporation data. Oecologia 156, 765-72.

Martínez del Rio C, Carleton SA (2012). How fast and how faithful - The dynamics of isotopic incorporation into animal tissues. Journal of Mammalogy 93, 3539.

Martínez del Rio C, Wolf BO (2005). Mass balance models for animal isotopic ecology. In: Starck JM, Wang T, eds. Physiological and Ecological Adaptations to Feeding in Vertebrates. Science Publishers, Enfield, pp. 141-74.

McCutchan JH, Lewis WM, Kendall C, McGrath CC (2003). Variation in trophic shift for stable isotope ratios of carbon, nitrogen, and sulfur. Oikos 102, 378-90.

Menke SB, Suarez AV, Tillberg CV, Chou CT, Holway DA (2010). Trophic ecology of the invasive argentine ant: Spatio-temporal variation in resource assimilation and isotopic enrichment. Oecologia 164, $763-71$. 
Mooney KA, Tillberg CV (2005). Temporal and spatial variation to ant omnivory in pine forests. Ecology 86, 1225-35.

Muldavin EH, Moore DI, Collins SL, Wetherill KR, Lightfoot DC (2008). Above ground net primary production dynamics in a northern Chihuahuan Desert ecosystem. Oecologia 155, 123-32.

Murray GW, Schramm D (1987). A comparative study of the diet of the wedge-snouted sand lizard, Meroles cuneirostris (Strauch), and the sand diving lizard, Aporosaura anchietae (Bocage), in the Namib Desert. Madoqua 15, 55-61.

Murray IW, Fuller A, Lease HM, Mitchell D, Wolf BO, Hetem RS (2014). The actively foraging desert lizard Pedioplanis husabensis behaviorally optimizes its energetic economy. Canadian Journal of Zoology 92, 905-13.

Murray IW, Fuller A, Lease HM, Mitchell D, Wolf BO, Hetem RS (2015). Low field metabolic rates for geckos of the genus Rhoptropus may not be surprising. Journal of Arid Environments 113, 35-42.

Murray IW, Fuller A, Lease HM, Mitchell D, Hetem RS (2016). Ecological niche separation of two sympatric insectivorous lizard species in the Namib Desert. Journal of Arid Environments 124, 225-32.

Noy-Meir I (1973). Desert ecosystems: Environment and producers. Annual Review of Ecology, Evolution, and Systematics 4, 25-51.

Noy-Meir I (1974). Desert ecosystems: Higher trophic levels. Annual Review of Ecology, Evolution, and Systematics 5, 195-214.

Ode DJ, Tieszen LL, Lerman JC (1980). The seasonal contribution of $\mathrm{C}_{3}$ and $\mathrm{C}_{4}$ plant species to primary production in a mixed prairie. Ecology 61, 1304-11.

Olivier J (1995). Spatial distribution of fog in the Namib. Journal of Arid Environments 29, 129-38.

Parnell AC, Inger R, Bearhop S, Jackson AL (2010). Source partitioning using stable isotopes: Coping with too much variation. PLOS ONE 5, e9672.

Peterson B, Fry B (1987). Stable isotopes in ecosystem studies. Annual Review of Ecology, Evolution, and Systematics 18, 293-320.

Pianka ER (1974). Niche overlap and diffuse competition. PNAS 71, 2141-5.

Pianka ER (1986). Ecology and Natural History of Desert Lizards. Princeton University Press, Princeton.

Picker M, Griffiths C, Weaving A (2004). Field Guide to Insects of South Africa. Struik, Cape Town.
Podlesak DW, McWilliams SR (2006). Metabolic routing of dietary nutrients in birds: Effects of diet quality and macronutrient composition revealed using stable isotopes. Physiological and Biochemical Zoology 79, 534-49.

Polis GA (1991). Complex trophic interactions in deserts: An empirical critique of food-web theory. American Naturalist 138, 123-55.

Polis GA, Hurd SD, Jackson CT, Piñero FS (1997). El Niño effects on the dynamics and control of an island ecosystem in the Gulf of California. Ecology 78, 1884-97.

Robinson MD, Cunningham AB (1978). Comparative diet of two Namib Desert sand lizards (Lacertidae). Madoqua 11, 41-53.

Roughgarden J (1974). Niche width: Biogeographic patterns among Anolis lizard populations. American Naturalist 108, 429-42.

Schachtschneider K, February EC (2010). The relationship between fog, floods, groundwater and tree growth along the lower Kuiseb River in the hyperarid Namib. Journal of Arid Environments 74, 1632-7.

Schoener TW (1977). Competition and the niche. In: Tinkle DW, Gans C, eds. Biology of the Reptilia. Academic Press, New York, pp. 35-136.

Scholtz CH, Holm E (1985). Insects of Southern Africa. Butterworths, Durban.

Schulze ED, Ellis R, Schulze W, Trimborn P, Ziegler H (1996). Diversity, metabolic types and $\delta 13 \mathrm{C}$ carbon isotope ratios in the grass flora of Namibia in relation to growth form, precipitation and habitat conditions. Oecologia 106, 352-69.

Simberloff D, Dayan T (1991). The guild concept and the structure of ecological communities. Annual Review of Ecology, Evolution, and Systematics 22, $115-43$.

Smith KF, Sharp ZD, Brown JH (2002). Isotopic composition of carbon and oxygen in desert fauna: investigations into the effects of diet, physiology, and seasonality. Journal of Arid Environments 52, 41930.

Still CJ, Berry JA, Collatz GJ, DeFries RS (2003). Global distribution of $\mathrm{C}_{3}$ and $\mathrm{C}_{4}$ vegetation: Carbon cycle implications. Global Biogeochemical Cycles 17, 1-14.

Straka J, Feldhaar H (2007). Development of a chemically defined diet for ants. Insectes sociaux $\mathbf{5 4}$, $100-4$. 
Symes CT, Woodborne S (2011). Estimation of food composition of Hodotermes mossambicus (Isoptera: Hodotermitidae) based on observations and stable carbon isotope ratios. Insect Science 18, 175-80.

Thuiller W, Midgley GF, Hughes GO et al. (2006). Endemic species and ecosystem sensitivity to climate change in Namibia. Global Change Biology 12, 759 76.

Uys V (2002). A Guide to the Termite Genera of Southern Africa. Plant Protection Research Institute Handbook No. 15. Agricultural Research Council, Pretoria.

Vitt LJ, Pianka ER, Cooper WE Jr, Schwenk K (2003). History and the global ecology of squamate reptiles. American Naturalist 162, 44-60.

Voigt CC, Rex K, Michener RH, Speakman JR (2008). Nutrient routing in omnivorous animals tracked by stable carbon isotopes in tissue and exhaled breath. Oecologia 157, 31-40.

Warne RW, Pershall AD, Wolf BO (2010a). Linking precipitation and $\mathrm{C}_{3}-\mathrm{C}_{4}$ plant production to resource dynamics in higher-trophic-level consumers. Ecology 91, 1628-38.

Warne RW, Gilman CA, Wolf BO (2010b). Tissue carbon incorporation rates in lizards: Implications for studies using stable isotopes in terrestrial ectotherms. Physiological and Biochemical Zoology 83, 608-17.

Watson JAL (1973). The worker caste of the hodotermitid harvester termites. Insectes Sociaux 20 , $1-20$.

Winter K, Lüttge U, Winter E, Troughton JH (1978). Seasonal shift from $\mathrm{C}_{3}$ photosynthesis to crassulacean acid metabolism in Mesembryanthemum crystallinum growing in its natural environment. Oecologia 34, $225-37$. 